\title{
Megújulás az alsó végtagi varicositas mǘtéti kezelésében
}

\author{
Bihari Imre dr. \\ Á+B Klinika, Budapest
}

\begin{abstract}
Míg a XX. század folyamán a hagyományos sebészi visszérmútétek folyamatos fejlesztése zajlott, addig a XXI. század első éveitől kezdve terjednek a különböző endovascularis eljárások. Fő előnyük, hogy sebészi feltárás nélkül, punkciókból, speciális katéterekkel zárják, hegesítik el a kezelendő saphenatörzseket. A beavatkozást megelőzően és annak során is ultrahanghasználat szükséges. A legszélesebb körben a lézeres visszérmútét terjedt el, melynek eredményei tovább javultak a lézeres crossectomia bevezetésével. Másik, gyakran alkalmazott műszer a rádiófrekvenciás koagulátor. További, hő alkalmazásával ható eljárás a forró gőzzel végzett mútét. Újabb módszer a cianoakriláttal történő érösszeragasztás. A már régóta ismert sclerotherapia továbbfejlesztése mind a felhabosított anyaggal, mind a mechanikus károsítással kombinált injekciós visszérkezelés. A szövődmények ritkábbak, mint a hagyományos sebészi eljárással, hiszen a mútéti feltárásból adódó komplikációk az eljárás lényegéből adódóan kiesnek.
\end{abstract}

Orv Hetil. 2018; 159(52): 2195-2201.

Kulcsszavak: varicositas, endovascularis kezelés, ultrahangvizsgálat, innovációk

\section{A turning point in the invasive treatment of lower limb varicosity}

During the 20th century, continuous development of classic varicose vein surgery was carried out. From the beginning of the 21 st century, however, new endovascular interventions were introduced. Compared to classic surgery, their main benefit is that no incision and dissection is necessary. Only catheters are used to scar the saphenous stems, which are introduced via punctures. Before and during the intervention, ultrasound is used. Laser surgery is the most popular option, and its outcomes have improved a lot with the introduction of laser crossectomy. Radiofrequency surgery is another intervention which is widely performed. A further heat ablation method is the steam operation. One newer technique is the cyanoacrylate tissue adhesive operation. The well-known practice of sclerotherapy has developed by turning the liquid sclerosant into foam, and by causing mechanical damage to the intimal layer of the vein. The new methods have fewer complications because these avoid incisions and dissections during the interventions.

Keywords: varicosity, endovascular treatment, ultrasound examination, innovations

Bihari I. [A turning point in the invasive treatment of lower limb varicosity]. Orv Hetil. 2018; 159(52): 2195-2201.

(Beérkezett: 2018. július 26.; elfogadva: 2018. augusztus 24.)

\section{Rövidítések}

$\mathrm{SFJ}=($ sapheno-femoral junction $)$ saphenofemoralis junctio; $\mathrm{UH}=$ ultrahang; VSM = vena saphena magna; $\mathrm{VSP}=$ vena saphena parva

$\mathrm{Az}$ alsó végtagi varicositas korszerü, invazív kezelését Trendelenburg vena (v.) saphena magna ligatura mütétjétől számítjuk. Az első ilyen mútéteket követően, már néhány év múlva nyilvánvalóvá vált, hogy a módszer nem igazán tökéletes, vagyis ezen a technikán még javítani kell, de a bemodinamikai alapelveken nyugvó, oki terápia alapjait mégis ez a beavatkozás vetette meg [1, 2]. Több mint egy évszázadon keresztül az ennek alapján kidolgozott, úgynevezett hagyományos sebészi módszerek uralták az invazív visszérkezelés lehetőségeit, melyeket a hazánkban átmenetileg tiltott sclerotherapia egészített ki [3]. A hagyományos sebészi mútét mind módszerében, mind műszerigényében folyamatosan fejlődött, egyre kevésbé invazívvá, ezáltal egyre kevésbé megterhelővé, 
ugyanakkor esztétikailag igényesebbé, a kiújulások tekintetében is eredményesebbé vált [4].

A XX. század utolsó éveiben már folytak a kísérletek a nem sebészi, hanem egy-egy punkción keresztül elvégezhető, endovénás beavatkozások irányába. Az áttörést Carlos Boné 1998-ban spanyol nyelven elhangzott, sikeres lézeres visszérmútétjéról szóló előadása, majd ennek a módszernek a 2001. évi publikációja hozta meg $[5,6]$. Azóta már más elven alapuló, más eszközöket igénylő módszerek is polgárjogot nyertek. Összefoglalóan ezeket endovénás varixmútéteknek nevezzük, amelyekre jellemző, hogy kevésbé megterhelőek, ennek köszönhetően a visszérmütétek kikerülhetnek a kórházakból, és szinte teljes mértékben járóbeteg-ellátás keretében végezbetők [7]. Ugyanakkor jelentős költségigényük van, ennek alapján érthető, hogy inkább a gazdaságilag fejlettebb országokban terjedtek el.

Az alábbiakban e módszereket kívánjuk bemutatni, amelyeket két csoportra szoktak osztani: az egyik csoportba a hőhatáson alapuló, vagy hőablatiós eljárások, a másikba a nem hövel ható módszerek tartoznak; a leírásokból kitűnik, melyik hová tartozik. Mindkét típus minimálinvazív; a nem hővel ható eljárások még kevesebb kellemetlenséggel járnak, mint a magas hőt használók. Ugyanakkor ez utóbbiak hatásossága, eredményessége vagy még nem érte el azt a fokot, amelyet a hővel ható eljárások, vagy még nem rendelkezünk megfelelő tapasztalattal a kiértékeléshez.

\section{Általános leírás}

Az alábbi beavatkozások közös jellemzője, hogy ezeket minden esetben alapos duplex ultrahangos (UH-) vizsgálat előzi meg. Ennek feladata nemcsak a subcutan hálózat anatómiájának felderítése, hanem a funkcionális eltérések, azaz a refluxforrások felfedése is $[8,9,10]$. Ez a diagnosztikus eljárás pontosabb, mint a korábban alkalmazott fizikális és kézi Doppler-vizsgálat és kevésbé invazív, mint a flebográfia. Továbbá az ultrahangos elővizsgálatot indokolja, hogy a beavatkozás alatt is ezt a müszert használjuk az érben lévő eszközök helyzetének azonosítására, vagyis az eljárás irányítására. A pontos UH-vizsgálat és mútét alatti irányítás kiemelten fontos a jobb eredmény elérésében, a mütéti roncsolás és a szövődmények csökkentésében. A mélyvénák vizsgálatára nem térünk ki, hiszen az a hagyományos mütét esetén ugyanúgy indokolt.

Nincs börmetszés, a beavatkozások a vénán belül, Seldinger-módszerrel bevezetett katéterekkel történnek. Jellemző, hogy ezek a beavatkozások kevésbé fájdalmasak, hiszen a fájdalom forrása elsősorban a bőr bemetszése és a szövetek rongálása lenne. Az endovascularis mütét kisfokú fájdalmának megelőzésére hőablatio esetén a lokálanesztetikumot tartalmazó hütőfolyadék elegendő, de a beteg kívánságára ennél nagyobb mértékű fájdalomcsillapítás is alkalmazható. A mütétet követően, rövidebb-hosszabb pihenés után, a beteg aznap elengedhe- tő. Kompressziós pólya vagy harisnya viselése általában rövidebb ideig ajánlott.

A visszérmütét lényegi része a saphenatörzsek beömlésének elzárása (crossectomia), a saphenatörzs megszüntetése és az elégtelen perforans vénák kiiktatása - ezeket végzik az endovascularis beavatkozások. Lehetnek azonban oldalágak, hálózatos visszerek és seprüvénák, amelyeket vagy ugyanazon ülésben, vagy az endovascularis rész megoldása után, külön beavatkozásként lehet eltüntetni. Ennek módszerei a hagyományos visszérmütét eljárásai, például horgolótűs eltávolítás vagy sclerotherapia. Mind az együléses, mint a kétüléses beavatkozásnak megvannak az előnyei és hátrányai, amelyeket célszerü a beteggel összehangolni.

\section{Varixmútét lézerrel}

A legnagyobb számban végzett endovénás beavatkozás. Ennek során a leggyakrabban a v. saphena magna (VSM) combszakaszába, ritkábban annak elülső oldalágába vagy a v. saphena parva (VSP) törzsébe vezetünk fényvezető szálat. A punkciót a saphenatörzs tágult szakaszának distalis végén vagy VSM esetén a térd medialis oldalán, felületesebben futó szakaszon végezzük. A szálat proximalis irányba, egészen a junctio (cross) alá toljuk. Lézerenergiaként korábban a 800-1000 nm-es hullámhosszú fényt használtuk, mely inkább a hemoglobinban nyelődik el, szemben az újabban használt 1400-1600 nm-essel, mely a szervezet víztartalmában. Az energiát az üvegszál vezeti; ez a lumenen belüli vért több mint 100 ${ }^{\circ} \mathrm{C}$-ra forrósítja, amely a sclerotherapiához hasonló módon, de annál erósebben, nemcsak az intimát, hanem az érfalat teljes vastagságában roncsolja, majd elhegesiti [11]. Az energiát elóször a saphenofemoralis junctio (SFJ) közvetlen közelébe, 5-20 mm-re a v. femoralistól adjuk le. A lézerszál helyzetét részben ultrahanggal, részben jelzőfény segítségével ellenőrizzük. A végeredmény szempontjából fontos a szál v. femoralistól való távolsága. Távolabbi $(20 \mathrm{~mm})$ hőleadás esetén a junctio és oldalágai nyitva maradnak. Enyhe tágulat esetén a hő hatására bekövetkező kollagénrost-rövidülés miatti beszúlkülés következtében, a billentyứk sufficienssé válnak. A felmérések szerint ebben az esetben a kiújulás hasonló gyakoriságú, mint a hagyományos mütétet követően [12]. A hagyományos, sebészi varicectomia után a kiújulások gyakori formája a neovascularisatio, amelyet a saphena rövid beömlőszakaszának ilyen módon végzett nyitva hagyásával, az ide ömlő oldalágak megőrzésével lehet elkerülni; ez az egyik indoka a v. femoralistól távolabbi besugárzásnak $[13,14]$. A másik indok a thromboemboliás szövődmények megelőzése. A lézeres beavatkozás utáni kiújulás formája más, mint a sebészi mútét utánié, itt az elzárt ér rekanalizációja vagy a junctióba nyíló accessoria anterior oldalág kitágulása a leggyakoribb.

Amennyiben a szál csúcsa a v. femoralishoz közelebb van $(5 \mathrm{~mm})$, akkor a beömlő saphenaszakasznak a v. fe- 
moralisig történő elzáródására számíthatunk, ezt lézeres crossectomiának nevezzük. Az újabb felmérésekból kiderült, hogy a korábbi feltételezés téves, a recidív varicositas igy ritkább, és a szövődmények sem gyakoribbak. Továbbá ez a módszer alkalmasnak bizonyult problémás esetekben is a mútét elvégzésére, így a jelentősen túltágult varicositas, a nagy testsúlyú betegek és a korábbi mútét után kiújult visszerességek megoldására is [15]. A saphenopoplitealis junctiót az ott futó idegek sérülésének elkerülésére csak $2 \mathrm{~cm}$-ig közelítjük meg.

A mútétet a junctio ellátása után a katéter distalis irányú, 1-1 cm-es lépésekben végzett kihúzásával folytatjuk, sokszorosan megismételve, egészen a punkció helyéig. Az energiacsomagot centiméterenként vagy lassan folyamatosan adjuk le, ami körülbelül 50-100 joule/ cm-t jelent. A tágabb szakaszokba több, a szúkebbekbe kevesebb energiát juttatunk. Az energiamennyiség kalkulálására az átmérő milliméterenkénti 6-12-szeres szorzásával számolunk. Proximalisan több, distalisan kevesebb hőt adunk le. A kezelhető saphenaátmérőnek nincs felső határa.

A környező szövetek sérülését az ér köré adott nagy mennyiségü $(5-10 \mathrm{ml} / \mathrm{cm})$, híg lokálanesztetikummal (esetenként előre hűtött, körülbelül $4{ }^{\circ} \mathrm{C}$-os) előzzük meg. Ha a junctio teljes elzárását tervezzük, akkor több energiát és több érzéstelenítő-hütő oldatot kell ide juttatni. Az elégtelen perforans vénákat is ezzel a módszerrel, de külön punkciókból zárjuk el, a szál hegyét ilyenkor a fascia szintjéig vezetjük.

A mütétet rugalmas pólya vagy kompressziós harisnya felhelyezésével fejezzük be. A beteg már a mútőasztalról leszállva ráléphet a lábára, járkálhat $[16,17]$. Mind rövid, mind hosszabb távon jó eredmények érhetők el [18].

\section{Mütét rádiófrekvenciás koagulátorral}

Ez az eljárás a lézerrel végzetthez hasonló hőablatio, amely ugyanazokon a vénatörzseken és -szakaszokon végezhető. Ebben az esetben azonban az ér lumenébe nem üvegszálat, hanem speciálisan összeállított elektródot vezetünk. Az elektródban olyan gyors az áram irányváltozása $(200-3000 \mathrm{kHz})$, hogy a szervezet egyéb részeit, izom- vagy idegsejteket nem ingerli vagy károsítja. Hatása csak azokra a szövetelemekre terjed ki, amelyekkel direkt érintkezésbe jut, ezt a tumescens anesztézián kívül manuális kompresszióval is elősegítjük. A roncsolás kisebb, mint $1 \mathrm{~mm}$ mélységig terjed. A szonda érzékeli a hőt és az elektromos tulajdonságokat, visszajelzést küld a generátorba, a környezet túlmelegedését és hőkárosodását így előzi meg. Korábban maximálisan csak 85 , újabban $120^{\circ} \mathrm{C}$-os hőmérsékletet hoz létre. A leadott hőmennyiséget többszörös vagy hosszabb hőleadási ciklus alkalmazásával lehet fokozni, hogy a kívánt roncsolóhatást elérjük. A beavatkozás idejét korábban hosszabbnak találták, mint a lézeres mütétét, az újabb készülékek ennél már jelentősen gyorsabbak. Korábban csak kisfokú saphenatágulatokra (rendszerint 4-6 mm átmérő) ajánlották, de speciális katéterrel már tágabb saphenatörzsekre is alkalmazható. Egyes szerzók a lézert, mások a rádiófrekvenciás koagulátor használatát helyezik előtérbe. Hatását általában - részben az alacsonyabb hőmérséklet, részben a generátornak küldött visszajelzés alapján - a lézernél kíméletesebbnek tartják, a kiújulási eredmények azonosak a lézerrel és a hagyományos mútéttel $[11,17$, $19,20]$.

\section{Endovascularis gőzmütét}

A gőz intraluminalis bevezetése is hasonló, kontrollált hőkárosodást tud előidézni, mint a lézer vagy a rádiófrekvenciás eljárás, hiszen hő hatására az előbbiek esetében is fejlődik gőz. Tehát ez is a hőablatiós eljárások közé tartozik. A gőzmütét feltalálója ugyanaz a René Milleret, aki a cryo módszert is bevezette. A katéteren keresztül a véna lumenébe, a megfelelő szakaszba juttatott gőz hőmérséklete $120^{\circ} \mathrm{C}$, egy-egy bepumpált gőzcsomag 60 joule energiának felel meg. Eredményessége inkább az oldalágak kezelésében bizonyult megbízhatónak, mint a saphenatörzsek vonatkozásában. Kíméletesebb, mint más hőablatiós eljárások, de a jelen esetben inkább a megfelelő destrukció lenne a cél. Kevesen alkalmazzák, hazai müszerről nem tudunk [21].

\section{Cianoakrilát ragasztó alkalmazása}

Az ismert, több mint 50 éve problémamentesen alkalmazott cianoakrilát szövetragasztót a fentiekhez hasonlóan katéterrel a véna lumenébe vezetjük, ahol az polimerizálódik, és az eret elzárja. Fontos a katéter hidrofób anyaga, az idő előtti megszilárdulás elkerülésére. A mindennapi használatú ragasztónál tapasztalt, szinte kristályos megkövesedés helyett a módosítások hatására rugalmasabb anyag marad a beavatkozás helyén. Jelenleg kétféle ragasztó van forgalomban, az egyik a viszkózusabb, lassan kötő (hazánkban csak ezt használjuk), míg a másik hígan folyó, gyorsan megszilárduló anyag. A saphenofemoralis junctiótól $5 \mathrm{~cm}$-rel distalisan kezdjük a ragasztó beadását, majd a viszkózus típussal $3 \mathrm{~cm}$-es szakaszonként megállva folytatjuk - míg a híg ragasztó esetén lassan és folyamatosan húzzuk kifelé a katétert, és közben fecskendezzük be az anyagot. A befecskendezést követően a katétert azonnal vissza kell húzni (nehogy beleragadjon az érbe), majd a junctio közelében 3 percig, attól distalisan fél percekig, ultrahangfejjel komprimáljuk a már kezelt szakaszt. Hígan folyó, gyorsan kötő ragasztótípus esetén a kompresszió folyamatos. A ragasztóból egy-egy helyre minimális, néhány tized ml-t, a saphenatörzs teljes hosszára általában alig több mint $1 \mathrm{ml}-\mathrm{t}$ adunk be. A ragasztó hatására a kezelt érben heg képződik.

Ennek a módszernek előnye, hogy nem hőhatáson alapul, ezért nem szükséges a véna köré hűtőfolyadék adása, és mivel szinte fájdalmatlan, jelentős mennyiségü lo- 
kálanesztetikum beadása sem. Mütét után kompressziós harisnyát vagy pólyát nem kell alkalmazni. Mivel egyéb gyógyszerbeadás sem történik, és a ragasztó percek alatt köt, a beavatkozást 10-20 perccel követöen a beteg távozhat, és folytathatja napi tevékenységét. A módszer kifejezetten alkalmas mindkét láb egy mütéten belüli kezelésére.

Az oldalágak megoldására a ragasztót nem ajánlják, mert az és a körülötte kialakuló heg az oldalágak felületesebb elhelyezkedése miatt hosszú ideig tapintható köteg marad, ezért zavaró lehet. Az esetek 10-20\%-ában az ér körül enyhe gyulladásos idegentest-reakció lép fel. $\mathrm{Az}$ itt felsorolt eljárások közül ennek van a legrövidebb múltja, ezáltal a legkevesebb tapasztalattal rendelkezünk. Annyit azonban már tudunk, hogy a szövődmények nem gyakoribbak, mint a többi endovascularis eljárásnál.

A saphenatörzsek elzárásának hatására a vénás nyomás lecsökken, és az enyhén tágult oldalágak visszább húzódnak, alkalmas esetben a visszeresség rendeződik. Amenynyiben az oldalágak nem szúnnek meg a kívánt mértékben, akkor 2-3 hónappal a ragasztás után rendszerint habsclerotherapiát végzünk; ilyenkor kétülésesnek tekintjük a beavatkozást. Az utólagos sclerotherapiánál a szokásos kompressziós kezelést alkalmazzuk, ezekben az esetekben tehát a beteg nem kerüli el ezt a kellemetlenséget, érdemes ilyenkor előre megfontolni az eljárás előnyeit és hátrányait. Tehát figyelembe kell venni, hogy a ragasztás csak kisfokú visszértágulat $(8 \mathrm{~mm}$-nél nem tágabb törzs és kevés, nem túl tág oldalág) esetén hatásos, máskor, az esetleges két menetben történő, elhúzódó beavatkozást, de leginkább azt, hogy költsége jelentősen felülmúlja más varixmútétekét $[19,22,23]$.

\section{Habsclerotherapia}

A 'levegóblokk' módszer (air-block technique) már legalább ötven éve ismert; lényege, hogy a szklerotizáló oldattal együtt beadott néhány levegőbuborék a vékony erekben - a felületi feszültség miatt - lassítja a hatóanyag tovaáramlását, s ezáltal fokozza a sclerotherapia hatását. Ennek továbbfejlesztése a felhabosítás, amely részben az említett módon, részben azáltal, hogy a hab nem keveredik a folyadékkal, hanem annak tetején helyezkedik el, jelentősen erősíti a szklerotizálás effektusát. Ezt körülbelül ugyanakkor fedezték fel, amikor a többi endovénás varixkezelési módszert.

A habkezeléshez ugyanazt az oldatot habositjuk fel, amelyet szklerotizálásra egyébként is alkalmazunk. A hab előállítása egyszerü, az egyik fecskendőbe szokványos szklerotizáló oldatot szívunk, a másikba pedig körülbelül ugyanannyi levegőt (az arány változtatható, és levegő helyett szén-dioxid is szóba jön). Az oldatot és a levegöt tartalmazó egy-egy fecskendőt egyenes darabbal vagy csappal kötjük össze, majd 10-20 alkalommal a teljes mennyiséget az egyik fecskendőból a másikba erôs nyomással átfecskendezzük: a turbulencia hatására a hab egyre homogénebb és finomabb szerkezetű lesz. A hab tartóssága 5-10 perc, ezalatt kell felhasználni, mivel ezután a folyadék és a gáz ismét szétválik, a hab effektivitása romlik. Bár a szövődményekrôl külön bekezdésben kívánunk szólni, már itt megemlítjük, hogy a tapasztalat szerint 10 ml-nél kisebb mennyiségű levegő iv. beadása nem okoz komplikációt.

A hab 3-10-szer hatásosabb, mint az oldat, a hab ugyanis nem keveredik a folyadékkal, jelen esetben a vérrel, ezáltal a vénába történő befecskendezés során a vért kinyomja a varixból, így nincs, ami a hatásosságát csökkentené. A hab további előnye, hogy ultrahanggal jól látjuk, áramlását jól követhetjük. Ezt kihasználva a v. saphena törzseknek, elsősorban a VSM combszakaszának és a VSP-törzsnek a kezelésére jól alkalmazhatjuk. A v. saphena törzsek punkcióját ultrahang-irányítással végezzük, és közben ellenőrizzük, hogy a beadott hab valóban intraluminalisan van, és áramlik tovább. Ha mindent jól végeztünk, akkor a habos gyógyszerre a véna jelentős spasmussal reagál. A v. saphena magna combszakaszának kezelésére 2-3 punkció vagy hosszú katéter szükséges. Általában egy vagy két alkalom elegendő az elzárásra. Vénás malformációk kezelésére is alkalmazható. Ha a saphenatörzs 6 mm-nél tágabb, akkor nem javasolt, mert ritkán eredményes, jelentős gyulladást válthat ki, és rövid idő után rekanalizálódik [11, 24-26].

Az összehasonlító tanulmányok az elzáródás gyakoriságát és időtartamát kevésbé jónak találták, mint a hőablatiós módszerekét, azonban könnyü, szinte fájdalmatlan kivitelezése és egyszerű ismétlése miatt néhány országban nagyon népszerü $[12,20]$.

\section{Mechanokémiai módszer}

Az eljárás lényege a tágult véna belső rétegeinek egyidejű fizikai és kémiai roncsolása. Katéteren keresztül drótot vezetünk a lumenbe, amelyet megpörgetve a belső rétegek fizikai roncsolását érjük el. Azt a roncsolt felszínt a sclerotherapiában rendszeresen alkalmazott polidokanololdattal tovább károsítjuk. A kombinációt szerzői nevén ClariVein-rendszernek nevezik [27]. Jelentős előnye a szinte teljes fájdalommentesség, amelyből következik az anesztézia szükségtelensége, vagyis a beteg azonnal folytathatja napi tevékenységét. Az eredmények függnek a beavatkozást végző orvos szakmai felkészültségétől, gyakorlatától [28].

\section{Lehetséges szövődmények}

Az endovénás beavatkozások okozta esetleges komplikációk többé-kevésbé egymáshoz hasonlóak, ezért együtt tárgyaljuk őket.

Mindenekelőtt ki kell emelnünk egy lényeges különbséget a hagyományos sebészi és az itt bemutatott endovénás eljárások között: a hagyományos mütét lényeges része a lágyéki vagy térdhajlati mütéti feltárás, míg az endovénás mütétek esetén ilyenre nincs szükség. Ez a mútéti rész a seb fájdalmassága mellett gyakran a szövőd- 
mények forrása is, ami az esetek mintegy 10-20\%-ában gondot okoz - például haematoma, nyirokérsérülés, suppuratio, artériasérülés, utóvérzés stb. A szövődmények megelőzésének is meg lehetnek a kellemetlen következményei: például a thromboembolia kémiai profilaxisa fokozott haematomaképződéssel jár. Sokan idegenkednek az antibiotikumok túlzott használatától, ugyanakkor ennek elhagyása esetén a lágyéki feltárást követően szeptikus komplikációk léphetnek fel [29]. Korábban felmerült a sebészi és az endovascularis eljárás kombinálása, mára kiderült, hogy ez egyértelmûen előnytelen [14]. Másik fontos különbség: míg a sebészi beavatkozás során a saphenatörzset eltávolítjuk, addig az endovascularis beavatkozások során az ér helyben marad, azt elhegesítjük, ezáltal az ér helyén fellépő, panaszokat okozó jelentős szöveti trauma és haematomaképződés elmarad. A komplikációk fö mennyiségi különbségét ez a módszertani differencia adja.

Míg a most felsorolt szövődmények csak a hagyományos sebészi eljárás kapcsán lépnek fel, addig az alábbiak mind a sebészi, mind az endovascularis eljárások során fenyegetnek.

Súlyossági sorrendben haladva, az enyhe, múló problémák közül megemlítjük, hogy az endovascularis eljárásoknál a suffusiók kisebb mértéküek. Ugyanakkor egy késői kellemetlenség, főleg felületesebb értörzsek esetén, átmeneti, de hónapokig tartó pigmentáció a ragasztást kivéve minden eljárást követően megjelenhet. A bőr égési sérülése kivételes ritkaság. Hasonlóan, mint a hagyományos sebészi mútétnél, a hőhatáson alapuló módszerek esetén is előfordulhat - bár más mechanizmus folytán az érzôidegek rendszerint átmeneti sérülése, vagyis érzéketlenség, esetleg túlzott érzékenység. Az idegsérülések kapcsán térhetünk át a súlyosabb szövődményekre. Rendkívül ritka, csak ezrelékekben kifejezhető - fóleg a VSP hőablatiós mütéte során - a mozgatóidegek károsodása. A térdhajlatban a VSP mélybe hajló szakasza esetenként nagyon közel fut az idegtörzsekhez, amelyek hő hatására sérülhetnek, és ez mozgászavart, bénulást okozhat. A mozgatóidegek sérülése a hagyományos mütét kapcsán is rendkívül ritka. Fenyegetőbb, minden vénamütétnél felmerülő szövődménylehetőség a thromboembolia. A kémiai profilaxis vonatkozásában nincs egységes álláspont, a rutinesetekben nem tartják szükségesnek [30]. Saját gyakorlatunkban, hőablatiós mútétek során, minden esetben alkalmazzuk [16, 18].

Speciális szövődmények egyes beavatkozástípusoknál lehetnek, ilyen a ragasztó használata esetén a múló idegentest-reakció a beadott ragasztó egyes szakaszai körül [22]. Másik módszer a habkezelés, melynek speciális szövődményei lehetnek: túl nagy mennyiség beadása köhögést, migrént, átmeneti vérnyomásesést és látászavart okozhat. Nem tisztázott, miért okoz panaszokat a hab, ha sokat adunk belőle, míg ugyanez kis mennyiségben nem vált ki reakciót. Mennyiségfüggő, másodlagos anyag, esetleg endothelinfelszabadulást feltételeznek [31]. Nyitott foramen ovale a buborékokat az artériás oldalra engedheti át, a nyílás ismert fennállása esetén a hab alkalmazása ezért kontraindikált. A súlyos szövődmények megelőzése fontos feladat, szerencsére a tömegesen alkalmazott beavatkozásokhoz képest alig fordulnak elő $[25,32]$.

\section{Megbeszélés}

Mint a fentiekből látható, alapvetően fontos a vénás rendszer előzetes UH-vizsgálata és a mútét alatti UHellenőrzés, valamint az utóvizsgálat. Minden említett eljárás és tanulmány erre a diagnosztikus módszerre épít. Enélkül nincs modern visszérgyógyászat. A varicositas forrásainak láthatóvá, mérhetővé tétele, a rendellenes áramlás mértékének megállapítása, az összeköttetések pontos felderítése mind jelentős segítség a minél kisebb, célratörő, az összes forrást megoldó beavatkozás elvégzéséhez. A korábban alkalmazott kézi Doppler-készülék annak idején az egyszerű fizikális vizsgálathoz képest jelentős fejlődést jelentett, de nem adott képet az erek pontos elhelyezkedéséről és az említett egyéb paraméterekról. A flebográfia ugyan minderre alkalmas volt, de invazivitása és veszélyei miatt nem lehet a mindennapi rutin része. Az UH-vizsgálat szükségességének hangsúlyozása különösen fontos, hiszen a modern, kíméletes eljárások alapja $[8,9,10]$.

A publikációk elsősorban az új módszerek bemutatására, esetleg egymással való összehasonlítására vállalkoznak $[12,20]$. Fontos kérdés azonban, hogy mit változtatnak ezek a módszerek a mindennapi ellátáson. Lényeges, hogy ma már nemcsak egyetlen módszer, a hagyományos sebészi varicectomia áll rendelkezésre a varicositas megoldására, hanem az itt felsorolt módszerek mindegyike. Ha a visszértágulatok egy durva osztályozásával kötjük össze a rendelkezésre álló módszereket, akkor a következő képet nyerjük: I. Az egészen apró, 1-2 mm-nél kisebb átmérőjű visszerek általában nem igényelnek mútéti beavatkozást, illetve nagyobb visszerekkel összefüggésben sem sebészi módszerekkel történik a megoldásuk, ezek tehát a jelen cikk köréből kiesnek. II. Az itt bemutatott módszerek elsősorban a már kitágult, esztétikailag zavaró, de nem túltágult, kevés fájdalmat, panaszt okozó, szövődménymentes (gyulladás, ödéma, bőrelváltozás, fekély stb.) visszerességek kezelésére ideálisak. Erre szinte mindegyik említett módszer megfelelő. III. A jelentősen túltágult, bőrelváltozásokat és más szövődményeket okozó vagy kiújult visszértágulatok az esetek többségében hagyományos sebészi visszérmütétre kerülnek, pedig az ilyen esetek kevésbé invazív módon, elsősorban lézer alkalmazásával is megoldhatók.

A módszerek közötti válogatás hazánkban fontos anyagi kérdés is. Ezenkívül a különböző módszerekkel rendelkezésre álló tapasztalatok vagy ezek hiánya is szempont lehet. A beteg számára a mindennapi munkából való kiesés, a fájdalomtûrő képesség, az esztétikai igények, az öltözködés, a felépülés gyorsasága mind lényeges szempont lehet a választáshoz. Figyelembe lehet 
1. táblázat $\mid A z$ alsó végtagi varicositas esetén végezhető mủtétek értékelése

\begin{tabular}{|c|c|c|c|c|c|c|c|}
\hline $\begin{array}{l}\text { Módszerek } \\
\text { Értékelések }\end{array}$ & Sebészi & Lézer & Rádiófr. & Gôz & $\mathrm{Hab}$ & MOCA & Ragasztó \\
\hline Méret & ++++ & ++++ & +++ & ++ & + & ++ & ++ \\
\hline $\begin{array}{l}\text { Nehéz } \\
\text { esetekre }\end{array}$ & ++++ & ++++ & ++ & + & + & + & + \\
\hline Tartósság & ++ & ++++ & ++++ & ++ & + & ++ & +++ \\
\hline Fájdalom & ++++ & ++ & ++ & ++ & + & + & + \\
\hline $\begin{array}{l}\text { Betegállo- } \\
\text { mány }\end{array}$ & ++++ & ++ & ++ & ++ & + & + & 0 \\
\hline $\begin{array}{l}\text { Szövőd- } \\
\text { mény }\end{array}$ & +++ & ++ & ++ & ++ & ++ & + & + \\
\hline Költség & ++ & +++ & +++ & +++ & + & ++ & ++++ \\
\hline
\end{tabular}

MOCA = mechanokémiai módszer; Rádiófr. = rádiófrekvenciás koagulátor

A nehéz esetekre megjelölésen elsősorban a körülírt, jelentős visszértágulattal bíró, túlsúlyos, kiújult visszeresség miatt jelentkező betegek és szövődményes esetek értendők. A jelen értékelés számos közlemény alapján került összeállításra, egyes cikkek vagy vélemények ettől akár jelentősen eltérhetnek, és további tapasztalatok birtokában változhatnak

venni a ma már fejlettebb technikájú hagyományos sebészi mútétet is, hiszen ez hazánkban a betegbiztosítás terhére végezhető, és UH-vizsgálattal kiegészítve még mindig versenyképes választás [33]. A különböző módszerek összehasonlító értékelését az 1. táblázat mutatja.

Régen azt mondtuk, az a jó sebész, aki egy módszert jól ismer, abban minden vonatkozásban jártas; ma már joggal várják el a kisebb invazivitású, a beteget kevésbé terhelő beavatkozást, vagyis ma a jó sebész az, aki átveszi az újabb módszereket, lépést tart a fejlődéssel.

$\mathrm{Az}$ ún. endovénás visszérmütétek egy további fejlődés alapjait vetették meg. Ennek lényeges része a bőrmetszés és feltárás nélküli, kevésbé megterhelő, kórházi befekvést már egyáltalán nem igénylő, fájdalmatlan vagy csak minimális fájdalommal járó, tehát kisebb érzéstelenítéssel megoldható, azonnali vagy gyors munkába állást rutinszerűen lehetôvé tévő beavatkozás. A különböző módszerek különböző előnyökkel rendelkeznek, közös bennük, hogy előrelépést eredményeztek, de teljes megoldást még nem. Mindezek figyelembevételével a nemzetközi ajánlások a hagyományos sebészi visszérműtéttel szemben előnyben részesítik az endovascularis eljárásokat $[19,34]$. A mütéti eredményt az $1 / a$ és $1 / b$ ábra mutatja.

\section{Következtetés}

A hagyományos sebészi visszérmütét technikájának mintegy százéves folyamatos fejlesztése, csiszolgatása után a XXI. századra váratlan, áttörő megújulás következett be. Ez a forradalmi változás az általános tudományos-technikai fejlődés következménye, amelynek egyéb vonatkozásokban is haszonélvezői vagyunk. A haladás egyrészt a mútét előtti és alatti UH-vizsgálat rutinszerü bevezetésének, másrészt a vágás, feltárás nélküli, apró szúrásokból, katéteres módszerrel, belülről, valamely modern technológiával elvégzett visszérhegesítés eredménye. Bár a kiújulási arányok jelentősen nem csökkentek, a mútéti és utófájdalom, a beavatkozás terhe és a szövődmények gyakorisága kisebb lett. A haladás egyértelmü, de reméljük, a fejlődés ezen a fokon még nem állt meg.
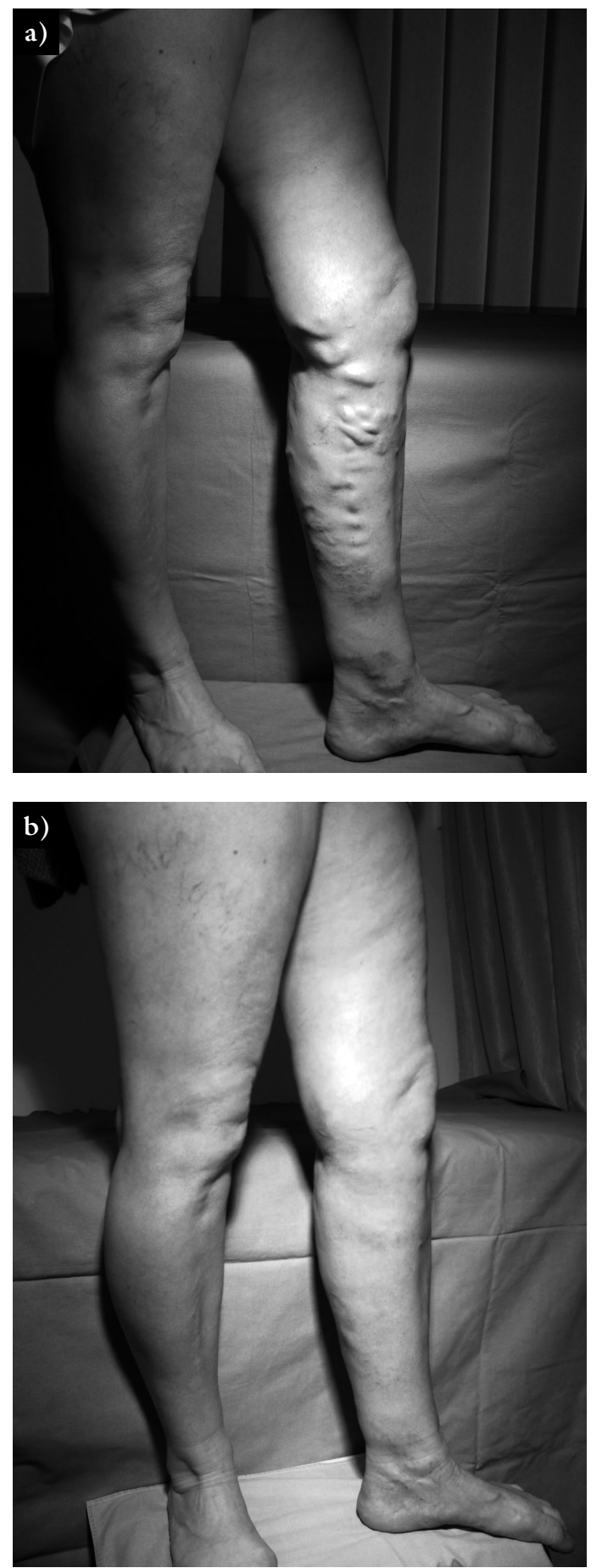

1. ábra

a) Vena saphena magna varicositas mútét elött. b) Lézeres visszérmútét után másfél évvel sem a varicositas, sem a beavatkozás nyoma nem látszik 
Anyagi támogatás: A közlemény megírása anyagi támogatásban nem részesült.

A szerző a cikk végleges változatát elolvasta és jóváhagyta.

Érdekeltségek: A szerzőnek nincsenek érdekeltségei.

\section{Irodalom}

[1] Trendelenburg F. On the ligature of the great saphenous vein in crural varicose vein cases. [Über die Unterbindung der Vena Saphena Magna bei Unterschenkelvarizen.] Beitr Klin Chir. 1890 7: 195. [German]

[2] Bihari I. Our predecessors on vein diseases. [Elödeink a vénák betegségeiről.] Orv Hetil. 1992; 133: 3210-3213. [Hungarian]

[3] Bihari I. The history of sclerotherapy. [A scleroterápia története.] Érbetegségek 1995; 2: 28-31. [Hungarian]

[4] Bihari I. Methods for lower limb varicose vein removal. [Az alsó végtagi varicositas mútéti eltávolításának módszerei.] Érbetegségek 1999; 6: 55-66. [Hungarian]

[5] Boné SC. Endoluminal treatment of varicose veins with diode laser. [Tratamiento endoluminal de las várices con láser de Diodo.] Rev Patol Vasc. 1999; 5: 35-46. [Spanish]

[6] Navarro L, Min RJ, Boné C. Endovenous laser: a new minimally invasive method of treatment for varicose veins. Preliminary observations using an $810 \mathrm{~nm}$ diode laser. Dermatol Surg. 2001; 27: 117-122.

[7] De Maeseneer M. The endovenous revolution. Br J Surg. 2011; 98: 1037-1038

[8] Coleridge-Smith Ph, Labropoulos N, Partsch H, et al. Duplex ultrasound investigation of the veins in chronic venous disease of the lower limbs. UIP consesus document. Part I. Basic principles. [Vénák duplex ultrahangvizsgálata az alsó végtag krónikus vénás betegségeiben. Nemzetközi Phlebologiai Unio konszenzus dokumentuma. I. rész: Alapelvek.] Érbetegségek 2006; 13: 87-97. [Hungarian]

[9] Sömjén Gy. The role of duplex ultrasound examination in phlebology. [A duplex ultrahangvizsgálat szerepe a phlebologiában.] Érbetegségek 2008; 15: 35-39. [Hungarian]

[10] Bihari I, Puskás A, Delfrate R, et al. Manoeuvres of haemodynamic ultrasound examinations of varicose veins. [Varicositas ultrahangos haemodynamikai vizsgálatának manőverei.] Érbetegségek 2016; 23: 3-9. [Hungarian]

[11] Goldman MP, Bergan JJ, Guex JJ. Sclerotherapy. 4th edn. Mosby, Philadelphia, PA, 2007.

[12] van der Velden SK, Biemans AA, De Maeseneer MG, et al. Fiveyear results of randomized clincal trial of conventional surgery, endovenous laser ablation and ultrasound-guided foam sclerotherapy in patients with great saphenous varicose veins. $\mathrm{Br} J$ Surg. 2015; 102: 1184-1194.

[13] Créton D. Neovascularisation. [Neovascularizáció.] Érbetegségek 2008; 15: 51-57. [Hungarian]

[14] De Maessener M. Neovascularisation: An adverse response to proper groin dissection. In: Bergan JJ. (ed.) The veinbook. Elsevier Press Inc, San Diego, CA, 2007; pp. 239-246.

[15] Bihari I, Zernoviczky F, Dragic P, et al. Laser crossectomy. [Crossectomia lézerrel.] Érbetegségek 2015; 22: 123-131. [Hungarian]

[16] Bihari I, Ayoub G, Bihari A. Five-year experience with varicose vein laser surgery. [Lézeres visszérmútéttel szerzett ötéves tapasztalatok.] Orv Hetil. 2012; 153: 1863-1869. [Hungarian]
[17] Morrison N. Endovascular operations (laser, radiofrequency) on varicose veins, technique, results, complications. [A varicositas endovasculáris mútétei - lézerrel és rádiófrekvenciás koagulátorral. Módszerek, eredmények, szövődmények.] Érbetegségek 2008; 15: 47-50. [Hungarian]

[18] Bihari I, Ayoub G, Bokros Sz, et al. 10 year experience with varicose vein laser surgery. [Lézeres visszérmủtéttel szerzett 10 éves tapasztalatok.] Érbetegségek 2017; 24: 15-25. [Hungarian]

[19] Nicolaides A, Kakkos S, Eklof B, et al. Management of chronic venous disorders of the lower limbs. Guidelines according to scientific evidence. Int Angiol. 2014; 33: 87-208.

[20] Lawaetz M, Serup J, Lawaetz B, et al. Comparison of endovenous ablation techniques, foam sclerotherapy and surgical stripping for great saphenous varicose veins. Extended 5-year follow-up of a RCT. Int Angiol. 2017; 36: 281-288.

[21] van den Bos RR, Milleret R, Neumann M. Proof-of-principle study of steam ablation as novel thermal therapy for saphenous varicose veins. J Vasc Surg. 2011; 53: 181-186.

[22] Bihari I, Szabó A. Varicose vein surgery with glue. [Visszérmútét ragasztással.] Érbetegségek 2018; 25: 17-22. [Hungarian]

[23] Proebstle TM, Alm J, Dimitri S, et al. The European multicenter cohort study on cyanoacrylate embolization of refluxing great saphenous veins. J Vasc Surg Venous Lymphat Disord. 2015; 3 : 2-7.

[24] Cavezzi A, Sigismondi G, Di Paolo S, et al. Foam sclerotherapy. [Hab-szkleroterápia.] Érbetegségek 2008; 15: 41-45. [Hungarian]

[25] Cabrera J, Cabrera J Jr, Garcia-Olmedo MA, et al. Treatment of varicose long saphenous veins with sclerosant in microfoam form. Long-term outcomes. Phlebology 2000; 15: 19-23.

[26] Greenberg JI, Angle N, Bergan JJ. Foam sclerotherapy. In: Gloviczki P. (ed.) Handbook of venous disorders. Arnold Publisher, London, 2009; pp. 380-389.

[27] Elias S, Raines JK. Mechanochemical tumescentless endovenous ablation: final results of the initial clinical trial. Phlebology 2012; 27: 67-72.

[28] Lam YL, Toonder IM, Wittens CH. ClariVein ${ }^{\circledR}$ mechano-chemical ablation: an interim analysis of a randomized controlled trial dose-finding study. Phlebology 2016; 31: 170-176.

[29] Mekako AI, Chetter IC, Coughlin PA, et al. Randomized clinical trial of co-amoxiclav versus no antibiotic prophylaxis in varicose vein surgery. Br J Surg. 2010; 97: 29-36.

[30] Qureshi MI, Davies AH. Thromboprophylaxis following superficial venous intervention. Phlebology 2016; 31: 77-80.

[31] Frullini A, Felice F, Furchielli S, et al. High production of endothelin after foam sclerotherapy: a new pathogenetic hypothesis for neurological and visual disturbances after sclerotherapy. Phlebology 2011; 26: 203-208.

[32] Morrison N. Studies on safety of foam sclerotherapy. In. Bergan J, Le Cheng V. (eds.) Foam sclerotherapy. A textbook. Royal Society of Medicine Press, London, 2008; pp. 183-192.

[33] Coughlin PA, Berridge DC. Is there a continuing role for traditional surgery? Phlebology 2015; 30(2S): 29-35.

[34] van der Velden SK, van den Bos RR, Pichot O, et al. Towards an individualized management strategy for patients with chronic venous disease: result of a Delphi consensus. Phlebology 2018; 33: 492-499. 